\title{
Assessment of the Mechanical Properties of Some Selected Sandcrete Hollow Blocks in Kogi State
}

\author{
Quadri Ajibola Ibrahim, Ijesoh Lawrence Irobekhian
}

\begin{abstract}
The current wave of the collapse of building structure all over Nigeria necessitates the need to carry out research on the mechanical properties of sandcrete hollow blocks. This study looks into the quality of blocks produced by block industries in Kogi state, Nigeria to ascertain its water absorption ratio, compressive strength and sieve analysis. In order to clarify these problems, the study is directed towards testing the strength properties of commercially produced sandcrete blocks; to verify whether the sandcrete block can be improved to achieve good quality in the building industries. A Total of five block industries were visited and twenty samples were picked at random from each of the selected block industry and also, soil samples obtained for soil tests in the laboratory. The analysis of results obtained was compared with the Nigerian Industrial Standard (NIS). The average water absorption rate of the sandcrete blocks for block industry $D$ was found to be $12.5 \%$ higher than the $12 \%$ maximum requirement of the [9]. The average compressive strength values of the sandcrete blocks range between $0.64 \mathrm{~N} / \mathrm{mm}^{2}$ and $0.87 \mathrm{~N} / \mathrm{mm}^{2}$ which when compared with standard, was found to be below the minimum requirement of the [9]. Inadequate mix ratio was observed to be one of the factors of poor quality sandcrete block production in this area. The study recommends compliance monitoring by the various regulatory body to ensure good quality of sandcrete block production.
\end{abstract}

Index Terms - Terms; Sandcrete blocks; Sieve analysis; Water absorption rate; Compressive Strength;

\section{INTRODUCTION}

The major problem facing the production of sandcrete hollow block is that the tested compressive strength of sandcrete hollow blocks produced by most commercial block making industries did not meet the required standard [6]. Studies carried out on the assessment of the quality of the blocks produced by commercial block-making industries revealed that majority of their blocks had 28-day dry strengths in the range of 0.50 to $1.5 \mathrm{~N} / \mathrm{mm} 2$ in Nigeria [4]; [5] Several reasons were advanced for the commercial production of substandard sandcrete hollow blocks. The major reasons were poor cement to sand mix ratio, inadequate curing, and poor workmanship [6]. The recent conflict of building collapses in Nigeria has been dramatic, in an attempt to gain insight into the problems associated, the study explores the question of to what extant is the quality of sandcrete blocks produced? In order to clarify this problem, the study is directed toward testing the Strength

Published on November 30, 2017

A.I. Quadri is an Assistant Lecturer at The Federal University of Technology, Akure. Nigeria. He completed his B.Eng and M.Eng. at the same University.(e-mail: aiquadri@ futa.edu.ng).

L.I. Ijesoh is currently working as a CIVIL ENGINEER in The Federal Ministry of Power, Works and Housing in Kogi State, Nigeria. (e-mail: integrity4law@yahoo.com).
Properties of Commercially produced sandcrete blocks; to affirm whether sandcrete blocks can be improved to achieve the good quality standard in the building and construction industry.

In the last couple of years, the construction industry has witnessed a high level of criticism and controversies over the issue of building collapse all over the country. The critical problem is the issue of using of sub-standard building materials and applied construction method or process [8]. Although some contractors and engineers use the approved standard laid down in the British and Nigerian institute's codes, other deviate from this largely due to their own selfish aim for the purposes of maximizing profit. As much as the economical use of materials is important, it is noteworthy that the safety of structures remains the most important [7]. Nigeria has been experiencing flood which usually affects walls of buildings and fences constructed with the sandcrete hollow block. Such walls are sometimes inundated for few days and may lead to large cracks or their collapse. The same applies to walls of buildings along coastal area [1]. The present method of simulating this incidence with the 28-day wet compressive strength of sandcrete hollow block may not be sufficient as some walls may not survive the inundation for up to 28 days before failure [4]. There is the need to characterize sandcrete hollow block immersed in water to determine the period at which the compressive strength of such inundated wall is a minimum. The result of such research may lead to a new approach in the method of design of load-bearing walls. Majority of sandcrete hollow blocks produced by the block making industries are substandard and this has led to huge losses in the process of placement and transportation of the product.

This study therefore, investigates the methods of producing hollow sandcrete blocks of standard sizes $450 \mathrm{~mm}$ x $225 \mathrm{~mm}$ x $225 \mathrm{~mm}$ (9 inches) from five block industries in Kogi state. Figure 1 shows the map of the study area in Kogi State.

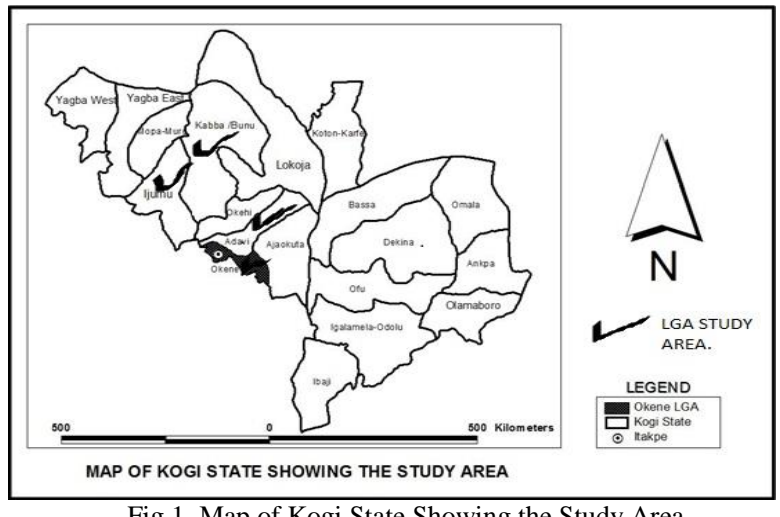

Fig.1. Map of Kogi State Showing the Study Area. 


\section{METHOD}

The study is designed to determine some selected mechanical properties of commercially produced sandcrete hollow blocks for construction in Kogi State, Nigeria. Samples of sandcrete blocks industries were acquired for testing from five commercial block making industries in Kogi State, most hollow sandcrete blocks produced are of two types. They are the 6 inches and 9 inches' hollow blocks 0f standard $450 \times 150 \times 225$ millimeters and $450 \times$ $225 \times 225$ millimeters respectively. They are produced by using hand mould and machine. Both hand moulded and machine vibrated blocks were produced with control mix and quality materials. In this research 9 inches' hollow blocks of standard size $450 \times 225 \times 225$ millimeters are used. The sandcrete blocks were made from the mixture of cement, fine aggregate (sand) and water based on the field observation. The cement used was ordinary Portland cement while the fine aggregate was mostly river sharp sand and the major source of water is borehole and drilled weir.

\section{A. Random Sampling}

Random probability cluster sampling technique was adopted for selection of the sandcrete blocks. In cluster sampling, the population is divided into segments from each of which a sample is chosen. The advantage of random sampling technique is that precision is not necessarily lost by observing less than the complete population. This saves labour, computing time, and cost. In random sampling every possible individual in a sample of a given size has exactly the same chance of being chosen. However, sampling error may occur if only a fraction of the population has been observed. Although different samples give different results, sampling errors become less important as sample size increases. Non-sampling errors may arise if the sampling procedure is not a representative of the total population. Such errors do not necessarily decrease as sample number increases.

Five (5) block industries labeled (A to E) were visited and twenty (20) samples of 9 inches sandcrete blocks each were collected from each of the industry. The samples collected were divided into equal part (i.e. 50 blocks each) and each was subjected to laboratory test to determine the water absorption rate and compressive strength test. The samples collected were labeled accordingly in other to differentiate them. During production of the blocks, it was observed that most block industries batch their materials by volume using wheelbarrow. Some others have no standard measures for batching of the materials as it was seen that they created a heap of sharp sand using eye gauge and add cement to it as against the standard mix proportion of 1:8 prescribed by [9]. Some of the labourers claimed that with their years of experience, batching by volume slows the production process so they prefer the eye gauge measured. None of the visited site used water-cement ratio, they only sprinkled water during mix.

\section{B. Laboratory Tests}

The test types conducted are of two types; the first was on the fine aggregates collected from the various visited block industries and the other test was on the Sandcrete blocks.
The tests carried out using the natural sand samples from the block industries are as follows:

\section{1) Sieve Analysis Test}

The experiment was conducted on each sand sample collected from each of the industries. The samples were spread out in the sun to dry for a period of 24 hours before the actual test was carried out. The experiment was carried out using the sieve apparatus for grading purposes according to [2]. $200 \mathrm{~g}$ of each of the sample from the five block industries was weighed using digital weighing apparatus. The sample was poured into the set of sieve aperture and vibrated vigorously with machine for about 5 minute. The mass of the sample retained in each of the sieve was measured and recorded. Consequently, the percentage mass retained and percentage mass passing the sieve set were obtained by calculation.

\section{2) Sandcrete Blocks Test}

\section{Bulk Density Determination}

Each sample of the blocks that were acquired from the block producing industries for the test purpose was numbered, and weighed in its dry state; during which mass of each block was read and recorded. The mass scale used was of $50 \mathrm{~kg}$ capacity and has $500 \mathrm{~g}$ graduations. The dimensions i.e., the length, wide and height of each block were then taken from this, the volume, and thereafter, the bulk densities were calculated using the results.

\section{a) Water Absorption}

Water absorption test is one of the major characteristics requirements specified by [9] for testing and verifying the quality of sandcrete blocks. Each sample of the purchased block which weight had been taken in the dry state was then fully immersed in water for 24hours, thereafter the wet blocks were weighed to get the percentage of water absorption capacity as expressed in (1).

$$
W_{r}=\frac{\left(W_{W}-W_{D}\right)}{W_{D}} \times 100 \%
$$

Where:

$W_{D}$ is the Weight of dry block,

$W_{W}$ is the Weight of the wet block after 24 hours in water. $W_{r}$ is the Water absorption capacity

\section{b) Compressive Strength}

The compression testing machine was used with a maximum load capacity of $1500 \mathrm{KN}$. Fifty (50) samples of dry and wet blocks each from the different block industries were crushed in order to obtain the crushing loads. With the net area of the blocks known, the compressive strength of each block was then calculated.

Compressive strength in this context is the ratio of the crushing load (force) a sample can sustain to its Net area.

\section{RESULT AND DiSCUSSION}

\section{A. Fine Aggregate}

Sieve Analysis

Table 1 to 5 present the results of the sieve analyses for the five visited block industries. It is seen that the percentage mass of the samples passing the $0.075 \mathrm{~mm}$ sieve for the selected industries is insignificant which denotes the presence of no silt in the samples. 
TABLE I: SIEVE ANALYSIS FOR BLOCK INDUSTRY A

\begin{tabular}{cccccc}
\hline \hline $\begin{array}{c}\text { Sieve } \\
\text { No }\end{array}$ & $\begin{array}{c}\text { Sieve } \\
\text { Size } \\
(\mathrm{mm})\end{array}$ & $\begin{array}{c}\text { Mass } \\
\text { retained } \\
(\mathrm{g})\end{array}$ & $\begin{array}{c}\text { \% mass } \\
\text { retained }\end{array}$ & $\begin{array}{c}\% \\
\text { cumulati } \\
\text { ve }\end{array}$ & \% passing \\
\hline 6 & 3.35 & 0 & 0 & 0 & 100 \\
8 & 2.36 & 21.0 & 10.5 & 10.5 & 89.5 \\
16 & 1.18 & 25.0 & 12.5 & 23.0 & 77.0 \\
30 & 0.600 & 29.0 & 14.5 & 37.5 & 62.5 \\
40 & 0.425 & 19.0 & 9.5 & 47.0 & 53.0 \\
50 & 0.300 & 25.0 & 2.5 & 59.5 & 41.5 \\
70 & 0.212 & 21.5 & 10.75 & 70.25 & 29.75 \\
100 & 0.150 & 29.0 & 14.5 & 84.75 & 15.25 \\
200 & 0.075 & 22.0 & 11.0 & 95.75 & 4.25 \\
& Pan & 8.5 & 4.25 & 100 & 0 \\
\hline \hline
\end{tabular}

TABLE II: SIEVE ANALYSIS FOR BLOCK INDUSTRY B

\begin{tabular}{cccccc}
\hline \hline $\begin{array}{c}\text { Sieve } \\
\text { No }\end{array}$ & $\begin{array}{c}\text { Sieve } \\
\text { Size } \\
(\mathrm{mm})\end{array}$ & $\begin{array}{c}\text { Mass } \\
\text { retained } \\
(\mathrm{g})\end{array}$ & $\begin{array}{c}\text { \% mass } \\
\text { retained }\end{array}$ & $\begin{array}{c}\% \\
\text { cumulati } \\
\text { ve }\end{array}$ & \% passing \\
\hline 6 & 3.35 & 0 & 0 & 0 & 100 \\
8 & 2.36 & 18.0 & 9.0 & 9.0 & 91.0 \\
16 & 1.18 & 29.0 & 14.5 & 23.5 & 76.5 \\
30 & 0.600 & 32.0 & 16.0 & 39.5 & 60.5 \\
40 & 0.425 & 21.0 & 10.5 & 50.0 & 50.0 \\
50 & 0.300 & 25.0 & 12.5 & 62.5 & 37.5 \\
70 & 0.212 & 19.0 & 9.5 & 72.0 & 28.0 \\
100 & 0.150 & 28.0 & 14.0 & 86.0 & 14.0 \\
200 & 0.075 & 15.0 & 7.5 & 93.5 & 6.5 \\
& Pan & 13.0 & 6.5 & 100 & 0 \\
\hline \hline
\end{tabular}

TABLE III: SIEVE ANALYSIS FOR BLOCK INDUSTRY C

\begin{tabular}{cccccc}
\hline \hline $\begin{array}{c}\text { Sieve } \\
\text { No }\end{array}$ & $\begin{array}{c}\text { Sieve } \\
\text { Size } \\
(\mathrm{mm})\end{array}$ & $\begin{array}{c}\text { Mass } \\
\text { retained } \\
(\mathrm{g})\end{array}$ & $\begin{array}{c}\% \text { mass } \\
\text { retained }\end{array}$ & $\begin{array}{c}\% \\
\text { cumulati } \\
\text { ve }\end{array}$ & $\begin{array}{c}\% \\
\text { passing }\end{array}$ \\
\hline 6 & 3.35 & 0 & 0 & 0 & 100 \\
8 & 2.36 & 19.0 & 9.5 & 9.5 & 90.5 \\
16 & 1.18 & 25.0 & 12.5 & 22.0 & 78.0 \\
30 & 0.600 & 28.0 & 14.0 & 36.0 & 64.0 \\
0 & 0.425 & 29.5 & 14.75 & 50.75 & 49.25 \\
50 & 0.300 & 21.0 & 10.5 & 61.25 & 38.75 \\
70 & 0.212 & 33.0 & 16.5 & 77.75 & 22.25 \\
100 & 0.150 & 22.0 & 11.0 & 88.75 & 11.25 \\
200 & 0.075 & 16.5 & 8.25 & 97.0 & 3.0 \\
& Pan & 6.0 & 3.0 & 100 & 0 \\
\hline \hline
\end{tabular}

TABLE IV: SIEVE ANALYSIS FOR BLOCK INDUSTRY D

\begin{tabular}{cccccc}
\hline \hline $\begin{array}{c}\text { Sieve } \\
\text { No }\end{array}$ & $\begin{array}{c}\text { Sieve } \\
\text { Size } \\
(\mathrm{mm})\end{array}$ & $\begin{array}{c}\text { Mass } \\
\text { retained } \\
(\mathrm{g})\end{array}$ & $\begin{array}{c}\% \text { mass } \\
\text { retained }\end{array}$ & $\begin{array}{c}\% \\
\text { cumulati } \\
\text { ve }\end{array}$ & $\begin{array}{c}\% \\
\text { passing }\end{array}$ \\
\hline 6 & 3.35 & 1.0 & 0.5 & 0.5 & 99.5 \\
8 & 2.36 & 21.5 & 10.75 & 11.25 & 88.75 \\
16 & 1.18 & 29.5 & 14.75 & 26.0 & 74.0 \\
30 & 0.600 & 19.0 & 9.5 & 35.5 & 64.5 \\
40 & 0.425 & 25.0 & 12.5 & 48.0 & 52.0 \\
50 & 0.300 & 20.0 & 10.0 & 58.0 & 42.0 \\
70 & 0.212 & 22.0 & 11.0 & 69.0 & 31.0 \\
100 & 0.150 & 30.0 & 15.0 & 84.0 & 16.0 \\
200 & 0.075 & 19.0 & 9.5 & 93.5 & 6.5 \\
& Pan & 13.0 & 6.5 & 100 & 0 \\
\hline \hline
\end{tabular}

TABLE IV: SIEVE ANALYSIS FOR BLOCK INDUSTRY E

\begin{tabular}{cccccr}
\hline \hline $\begin{array}{c}\text { Sieve } \\
\text { No }\end{array}$ & $\begin{array}{c}\text { Sieve } \\
\text { Size } \\
(\mathrm{mm})\end{array}$ & $\begin{array}{c}\text { Mass } \\
\text { retained } \\
(\mathrm{g})\end{array}$ & $\begin{array}{c}\% \text { mass } \\
\text { retained }\end{array}$ & $\begin{array}{c}\% \\
\text { cumulati } \\
\text { ve }\end{array}$ & $\begin{array}{c}\% \\
\text { passing }\end{array}$ \\
\hline 6 & 3.35 & 2.0 & 1.0 & 1.0 & 99.0 \\
8 & 2.36 & 24.0 & 12.0 & 13.0 & 87.0 \\
16 & 1.18 & 20.0 & 10.0 & 23.0 & 77.0 \\
30 & 0.600 & 29.0 & 14.5 & 37.5 & 62.5 \\
40 & 0.425 & 19.5 & 9.75 & 47.25 & 52.7 \\
50 & 0.300 & 17.5 & 8.75 & 56.0 & 44.0 \\
70 & 0.212 & 23.0 & 11.5 & 67.5 & 32.5 \\
100 & 0.150 & 30.0 & 15.0 & 82.5 & 17.5 \\
200 & 0.075 & 20.0 & 10.0 & 92.5 & 7.5 \\
& Pan & 15.0 & 7.5 & 100 & 0 \\
\hline \hline
\end{tabular}

PARTICLE SIZE DISTRIBUTION CURVE BS SIEVES

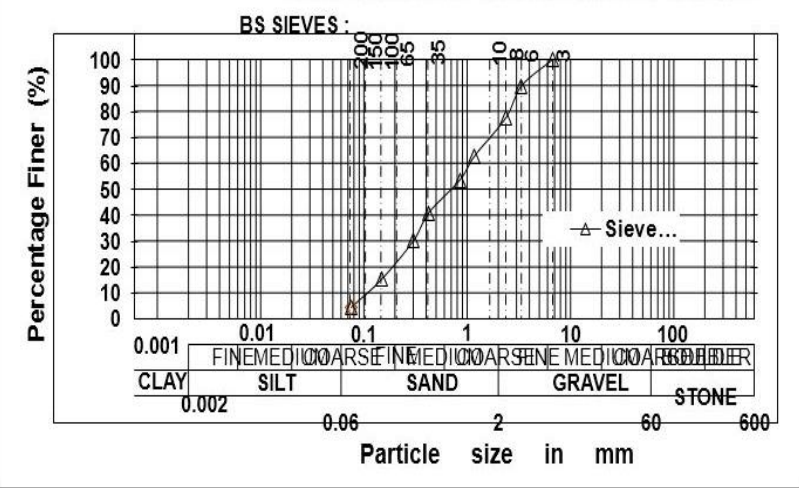

Fig. 2: Particle Size Distribution Curve for Block Industry A

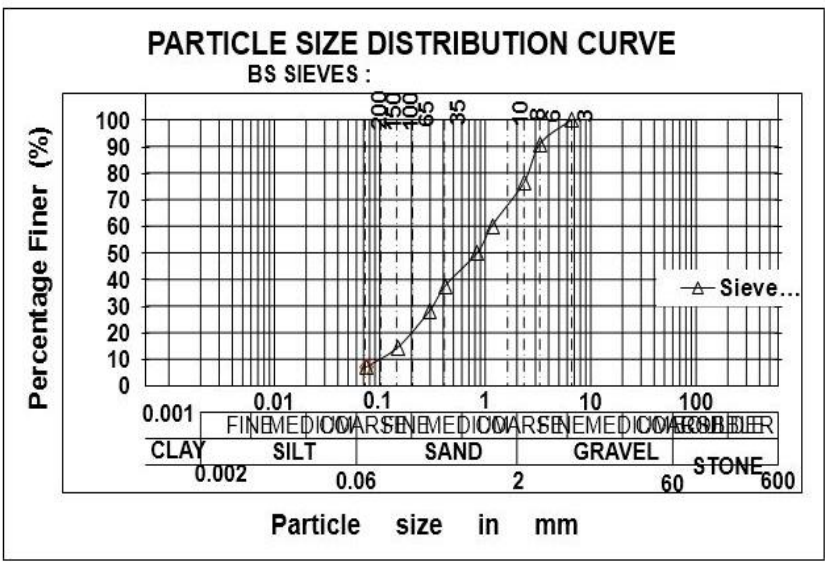

Fig.3: Particle Size Distribution Curve for Block Industry B

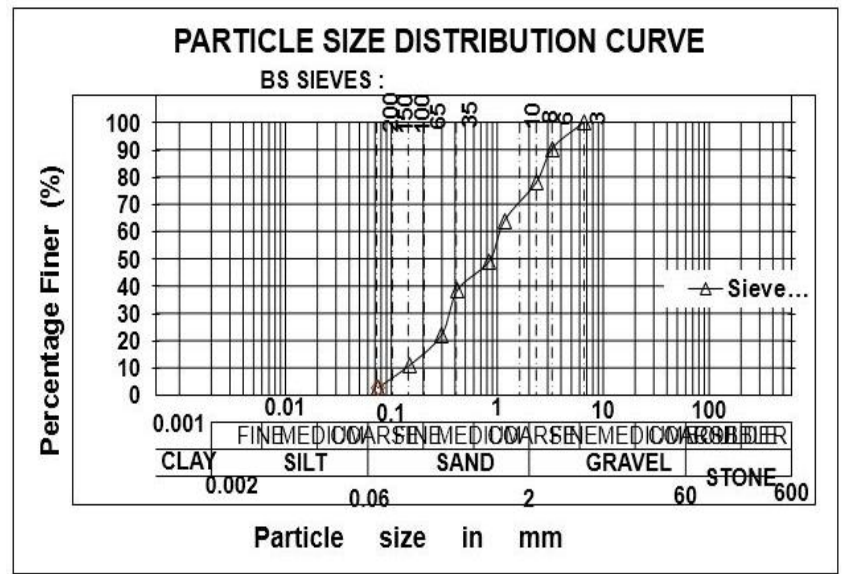

Fig.4: Particle Size Distribution Curve for Block Industry C.

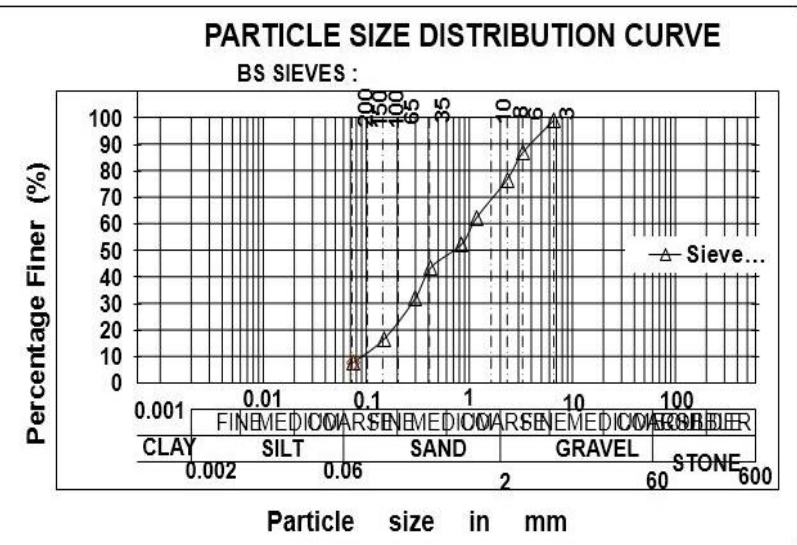

Fig. 5: Particle Size Distribution Curve for Block Industry D. 


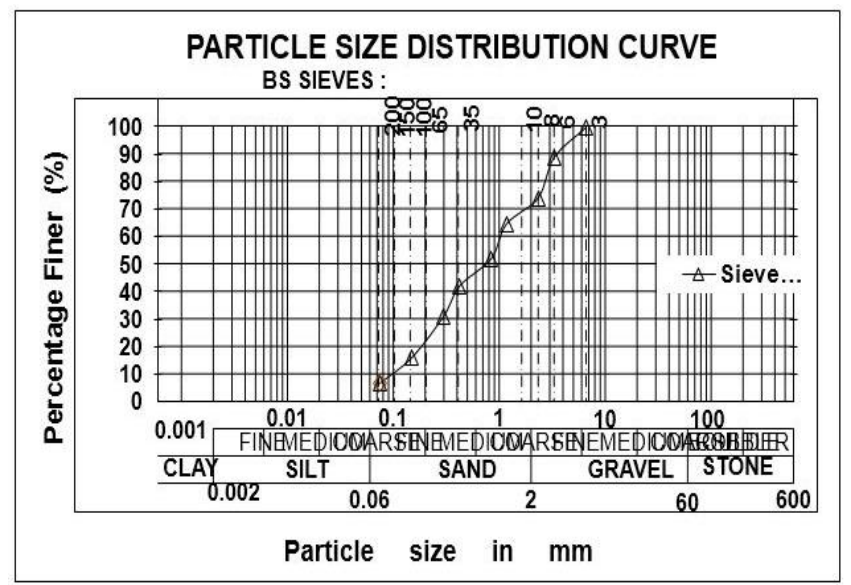

Fig. 6: Particle Size Distribution Curve for Block Industry E.

On examine figures 2 to 6 , it is seen that there is no presence of silt/clay, however fine gravels contributed some significant percentage to the samples. This could promote rapid absorption of water and consequently upon drying, could leave little pores on the sandcrete block if not properly mixed. Thus, produce a weak block which can affect the initial and final setting time, thereby affecting the strength of the sandcrete block.

\section{B. Sandcrete Hollow Block Tests}

The test results determination of bulk density i.e., dry density and wet density, water absorption capacities of blocks, and compressive strength of blocks are presented.

\section{1) Bulk Density}

The test results for the determination of the bulk densities of the sandcrete blocks from the various block industries in accordance with [2] are presented in tables 6 to 10 .

TABLE VI: BULK DENSITY FOR BLOCK INDUSTRY A

\begin{tabular}{|c|c|c|c|c|c|}
\hline $\begin{array}{c}\text { Block } \\
\text { Sample }\end{array}$ & $\begin{array}{c}\text { Volume } \\
\text { of block } \\
\left(\mathrm{m}^{3}\right)\end{array}$ & $\begin{array}{c}\text { M1 } \\
\text { Wt. of dry } \\
\text { block (kg) }\end{array}$ & $\begin{array}{l}\text { M2 Wt. of } \\
\text { block after } \\
24 \mathrm{hrs}(\mathrm{kg})\end{array}$ & $\begin{array}{l}\text { Dry Density } \\
\left(\mathrm{kg} / \mathrm{m}^{3}\right)\end{array}$ & $\begin{array}{l}\text { Wet density } \\
\left(\mathrm{kg} / \mathrm{m}^{3}\right)\end{array}$ \\
\hline 1 & \multirow{11}{*}{ 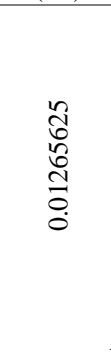 } & 16.9 & 18.9 & 1335.3 & 1493.3 \\
\hline 2 & & 11.3 & 18.9 & 1366.9 & 1493.3 \\
\hline 3 & & 17.2 & 18.3 & 1359.0 & 1445.9 \\
\hline 4 & & 16.4 & 19.2 & 1295.8 & 1517.0 \\
\hline 5 & & 16.8 & 19.4 & 1327.4 & 1532.8 \\
\hline 6 & & 17.9 & 18.9 & 1414.3 & 1493.3 \\
\hline 7 & & 18.1 & 19.0 & 1430.1 & 1501.2 \\
\hline 8 & & 16.3 & 19.3 & 1287.9 & 1524.9 \\
\hline 9 & & 16.1 & 18.1 & 1272.1 & 1430.0 \\
\hline \multirow[t]{2}{*}{10} & & 16.8 & 18.7 & 1327.4 & 1477.5 \\
\hline & & Average & & 1341.62 & 1490.92 \\
\hline
\end{tabular}

TABLE VII: BULK DENSITY FOR BLOCK INDUSTRY B

\begin{tabular}{|c|c|c|c|c|c|}
\hline $\begin{array}{c}\text { Block } \\
\text { Sample }\end{array}$ & $\begin{array}{l}\text { Volu } \\
\text { me of } \\
\text { block } \\
\left(\mathrm{m}^{3}\right)\end{array}$ & $\begin{array}{c}\mathrm{M}_{1} \\
\text { Wt. of dry } \\
\text { block } \\
(\mathrm{kg})\end{array}$ & $\begin{array}{c}\mathrm{M}_{2} \\
\text { Wt. of block } \\
\text { after } 24 \mathrm{hrs} \\
(\mathrm{kg})\end{array}$ & $\begin{array}{c}\text { Dry } \\
\text { density } \\
\left(\mathrm{kg} / \mathrm{m}^{3}\right)\end{array}$ & $\begin{array}{c}\text { Wet density } \\
\left(\mathrm{kg} / \mathrm{m}^{3}\right)\end{array}$ \\
\hline 1 & \multirow{11}{*}{ 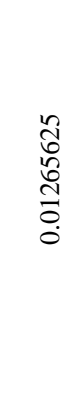 } & 16.8 & 18.4 & 1327.41 & 1453.83 \\
\hline 2 & & 16.4 & 17.9 & 1295.80 & 1414.32 \\
\hline 3 & & 17.0 & 18.7 & 1343.21 & 1477.53 \\
\hline 4 & & 16.9 & 18.5 & 1335.31 & 1461.72 \\
\hline 5 & & 18.2 & 19.3 & 1438.02 & 1524.94 \\
\hline 6 & & 16.6 & 17.9 & 1311.60 & 1398.52 \\
\hline 7 & & 16.0 & 17.7 & 1264.20 & 1398.52 \\
\hline 8 & & 16.8 & 18.4 & 1327.41 & 1453.83 \\
\hline 9 & & 17.5 & 19.0 & 1382.72 & 1501.23 \\
\hline \multirow[t]{2}{*}{10} & & 17.0 & 18.9 & 1343.21 & 1493.33 \\
\hline & & Average & & 1336.89 & 1457.78 \\
\hline
\end{tabular}

TABLE VIII: BULK DENSITY FOR BLOCK INDUSTRY C

\begin{tabular}{|c|c|c|c|c|c|}
\hline $\begin{array}{c}\text { Block } \\
\text { Sample }\end{array}$ & $\begin{array}{l}\text { Volum } \\
\text { e of } \\
\text { block } \\
\left(\mathrm{m}^{3}\right)\end{array}$ & $\begin{array}{c}\mathrm{M}_{1} \mathrm{Wt} . \\
\text { of dry } \\
\text { block } \\
(\mathrm{kg})\end{array}$ & $\begin{array}{c}\mathrm{M}_{2} \\
\text { Wt. of block } \\
\text { after } 24 \mathrm{hrs} \\
(\mathrm{kg})\end{array}$ & $\begin{array}{c}\text { Dry } \\
\text { density } \\
\left(\mathrm{kg} / \mathrm{m}^{3}\right)\end{array}$ & $\begin{array}{c}\text { Wet density } \\
\left(\mathrm{kg} / \mathrm{m}^{3}\right)\end{array}$ \\
\hline 1 & \multirow{10}{*}{ 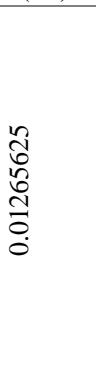 } & 16.1 & 18.3 & 1272.20 & 1445.93 \\
\hline 2 & & 16.3 & 17.9 & 1287.90 & 1414.32 \\
\hline 3 & & 17.0 & 18.9 & 1343.21 & 1493.33 \\
\hline 4 & & 16.2 & 18.4 & 1280.00 & 1453.83 \\
\hline 5 & & 15.9 & 18.2 & 1256.30 & 1438.02 \\
\hline 6 & & 16.5 & 18.1 & 1303.70 & 1430.12 \\
\hline 7 & & 16.9 & 18.6 & 1335.31 & 1469.63 \\
\hline 8 & & 17.2 & 18.1 & 1359.01 & 1430.12 \\
\hline 9 & & 16.7 & 17.9 & 1319.51 & 1414.32 \\
\hline \multirow[t]{2}{*}{10} & & 16.2 & 18.5 & 1280.00 & 1461.73 \\
\hline & \multicolumn{2}{|c|}{ Average } & & 1303.71 & 1445.14 \\
\hline
\end{tabular}

TABLE XI: BULK DENSITY FOR BLOCK INDUSTRY D

\begin{tabular}{|c|c|c|c|c|c|}
\hline $\begin{array}{c}\text { Block } \\
\text { Sample }\end{array}$ & $\begin{array}{c}\text { Volu } \\
\text { me of } \\
\text { block } \\
\left(\mathrm{m}^{3}\right)\end{array}$ & $\begin{array}{c}\mathrm{M}_{1} \\
\text { Wt. of } \\
\text { dry block } \\
(\mathrm{kg})\end{array}$ & $\begin{array}{c}\mathrm{M}_{2} \\
\text { Wt. of } \\
\text { block after } \\
24 \mathrm{hrs}(\mathrm{kg})\end{array}$ & $\begin{array}{c}\text { Dry } \\
\text { density } \\
\left(\mathrm{kg} / \mathrm{m}^{3}\right)\end{array}$ & $\begin{array}{l}\text { Wet density } \\
\qquad\left(\mathrm{kg} / \mathrm{m}^{3}\right)\end{array}$ \\
\hline 1 & \multirow{11}{*}{ 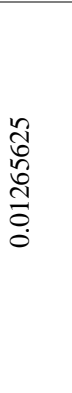 } & 15.9 & 17.8 & 1256.30 & 1406.42 \\
\hline 2 & & 16.2 & 18.5 & 1280.00 & 1461.73 \\
\hline 3 & & 16.4 & 18.6 & 1295.80 & 1469.63 \\
\hline 4 & & 16.3 & 18.5 & 1287.90 & 1461.63 \\
\hline 5 & & 16.0 & 17.9 & 1264.20 & 1461.73 \\
\hline 6 & & 16.7 & 18.8 & 1319.51 & 1414.32 \\
\hline 7 & & 16.5 & 17.9 & 1303.70 & 1485.43 \\
\hline 8 & & 16.2 & 18.5 & 1280.00 & 1414.32 \\
\hline 9 & & 16.4 & 18.1 & 1295.80 & 1461.73 \\
\hline \multirow[t]{2}{*}{10} & & 16.0 & 18.3 & 1264.20 & 1430.12 \\
\hline & & Average & & 1284.74 & 1445.14 \\
\hline
\end{tabular}

TABLE X: BULK DENSITY FOR BLOCK INDUSTRY E

\begin{tabular}{|c|c|c|c|c|c|}
\hline $\begin{array}{c}\text { Block } \\
\text { Sample }\end{array}$ & $\begin{array}{c}\text { Volu } \\
\text { me of } \\
\text { block } \\
\left(\mathrm{m}^{3}\right)\end{array}$ & $\begin{array}{c}\quad \mathrm{M}_{1} \\
\text { Wt. of dry } \\
\text { block }(\mathrm{kg})\end{array}$ & $\begin{array}{l}\mathrm{M}_{2} \mathrm{Wt} \text {. of } \\
\text { block after } \\
24 \mathrm{hrs}(\mathrm{kg})\end{array}$ & $\begin{array}{c}\text { Dry } \\
\text { density } \\
\left(\mathrm{kg} / \mathrm{m}^{3}\right)\end{array}$ & $\begin{array}{c}\text { Wet density } \\
\left(\mathrm{kg} / \mathrm{m}^{3}\right)\end{array}$ \\
\hline 1 & \multirow{11}{*}{ 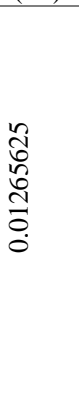 } & 16.9 & 18.2 & 1335.31 & 1438.02 \\
\hline 2 & & 16.1 & 18.0 & 1272.10 & 1422.22 \\
\hline 3 & & 16.4 & 17.8 & 1295.80 & 1406.42 \\
\hline 4 & & 15.9 & 17.5 & 1256.30 & 1382.72 \\
\hline 5 & & 16.7 & 18.3 & 1319.51 & 1445.93 \\
\hline 6 & & 16.2 & 18.4 & 1280.00 & 1453.83 \\
\hline 7 & & 17.0 & 18.9 & 1343.21 & 1493.33 \\
\hline 8 & & 16.3 & 17.9 & 1287.90 & 1414.32 \\
\hline 9 & & 16.5 & 18.5 & 1303.70 & 1461.73 \\
\hline \multirow[t]{2}{*}{10} & & 16.0 & 18.3 & 1264.20 & 1445.93 \\
\hline & & Average & & 1295.80 & 1436.45 \\
\hline
\end{tabular}

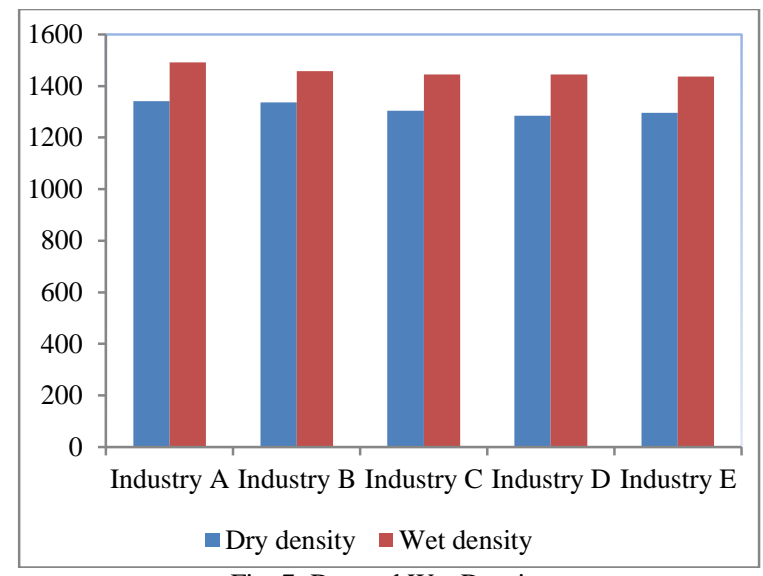

Fig. 7: Dry and Wet Density 
The results from Tables 6 to 10 and figure 7 show that bulk density is below the recommended value [2] minimum limit of $1920 \mathrm{~kg} / \mathrm{m}^{3}$ for individual block and $2020 \mathrm{~kg} / \mathrm{m}^{3}$ for an average of three or more blocks. It is seen that, block industry A has the highest wet density of $1532.80 \mathrm{~kg} / \mathrm{m}^{3}$ (individual block, sample 5) and $1490.92 \mathrm{~kg} / \mathrm{m}^{3}$ as the highest average wet density. The wet density for all the block industries stood at par in Figure 7, though block industry A has the highest value among them. The same flow is observed in the dry density.

This reveals improper compaction which is not within acceptable limits.

\section{2) Water Absorption}

On examining table 11 and figure 8 , results of the average water absorption rate obtained reveal that block industry D has the highest percentage of water absorption rate when compared with the maximum absorption rate of $12 \%$ recommended by [9]. Block industry B with the lowest water absorption rate could have the highest performance strength among the block industries. Hence, the effect of high percentage of water absorption rate than the recommended $12 \%$ by [9] is that when exposed to inundation, the rate of permeability of those blocks will be high, consequently become weakened and eventually fail.

\begin{tabular}{|c|c|c|c|c|c|}
\hline $\begin{array}{c}\text { Block } \\
\text { sampl } \\
\mathrm{e}\end{array}$ & $\begin{array}{c}\frac{\left(M_{1}-M_{2}\right)}{M_{1}} \\
\times 100 \\
\text { Industry } \\
\mathrm{A}(\%)\end{array}$ & $\begin{array}{c}\frac{\left(M_{1}-M_{2}\right)}{M_{1}} \\
\times 100 \\
\text { Industry } \\
\mathrm{B}(\%)\end{array}$ & $\begin{array}{l}\frac{\left(M_{1}-M_{2}\right)}{M_{1}} \\
\times 100 \\
\text { Industry } \\
\mathrm{C}(\%)\end{array}$ & $\begin{array}{l}\frac{\left(M_{1}-M_{2}\right)}{M_{1}} \\
\times 100 \\
\text { Industry } \\
\mathrm{D}(\%)\end{array}$ & $\begin{array}{l}\frac{\left(M_{1}-M_{2}\right)}{M_{1}} \\
\times 100 \\
\text { Industry } \\
\mathrm{E}(\%)\end{array}$ \\
\hline 1 & 56,250 & 0.85 & 0.93 & 0.62 & 0.59 \\
\hline 2 & 56,250 & 0.90 & 0.97 & 0.71 & 0.73 \\
\hline 3 & 56,250 & 0.73 & 0.81 & 0.78 & 0.67 \\
\hline 4 & 56,250 & 0.99 & 0.79 & 0.59 & 0.73 \\
\hline 5 & 56,250 & 0.73 & 0.86 & 0.70 & 0.57 \\
\hline 6 & 56,250 & 0.77 & 0.59 & 0.55 & 0.80 \\
\hline 7 & 56,250 & 0.80 & 0.73 & 0.67 & 0.55 \\
\hline 8 & 56,250 & 0.84 & 0.78 & 0.55 & 0.55 \\
\hline 9 & 56,250 & 0.71 & 0.94 & 0.53 & 0.52 \\
\hline 10 & 56,250 & 0.72 & 0.74 & 0.71 & 0.72 \\
\hline $\begin{array}{l}\text { Avera } \\
\text { ge }\end{array}$ & 0.80 & 0.81 & 0.64 & 0.64 & 0.72 \\
\hline
\end{tabular}

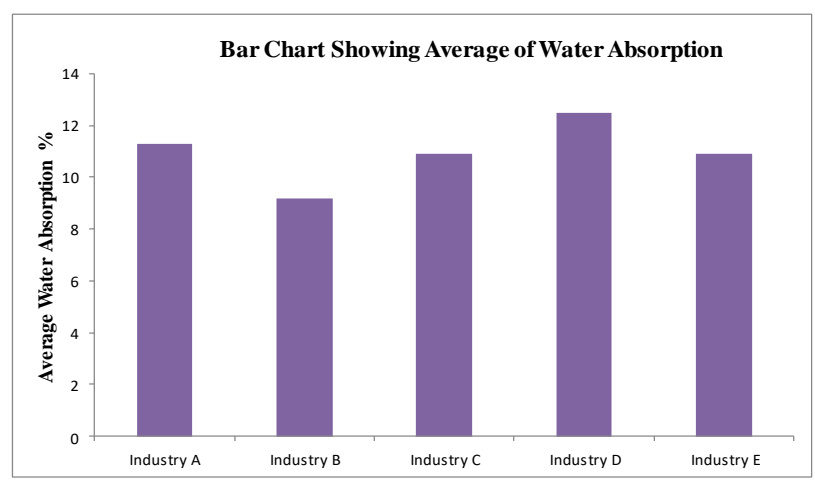

Fig. 8: Average Water Absorption of Blocks

\section{3) Compressive Strength Test}

The result of the dry and wet compressive strengths tests conducted on the sandcrete blocks is presented in Tables 12 and 13. The results from the test are an indication that the compressive strength of the individual sandcrete blocks ranges between $0.53 \mathrm{~N} / \mathrm{mm}^{2}$ to $1.24 \mathrm{~N} / \mathrm{mm}^{2}$ for the dry compressive strength and $0.52 \mathrm{~N} / \mathrm{mm}^{2}$ to $0.99 \mathrm{~N} / \mathrm{mm}^{2}$ for the wet compressive strength. These compressive strengths fall far below what is recommended by Nigerian Industrial standard [9] for individual (non-load bearing wall) block which is stipulated as $2.5 \mathrm{~N} / \mathrm{mm}^{2}$; [2] recommends that the compressive strength of five blocks shall not be less than 3.5 $\mathrm{N} / \mathrm{mm}^{2}$. It is observed from the results that the highest strength attained for individual blocks is $1.24 \mathrm{~N} / \mathrm{mm}^{2}$ (sample 3 block industry A). Block industry B has the highest average compressive strength (both dry and wet) as shown in figure 9, while block industry D has the least. It is also observed that average values for dry compressive strengths in the entire block industries are higher than any of the average wet compressive strengths as presented in figure 9. However, none of the blocks measures up to the minimum required average of $1.75 \mathrm{~N} / \mathrm{mm}^{2}$ as recommended by the [3]. The improper quality of the blocks could be attributed to poor mix ratio and inadequate curing of the sandcrete blocks. The [9] standard specifies the use of mix ratio 1:8 current sand proportion to achieve the minimum compressive strength value of $2.5 \mathrm{~N} / \mathrm{mm}^{2}$ for well as 0.45 water cement ratio and maximum specified $12 \%$ water absorption.

TABLE XII: DRY COMPRESSIVE STRENGTH TEST RESUlt FOR THE FIVE

\begin{tabular}{|c|c|c|c|c|c|}
\hline \multicolumn{6}{|c|}{ BLOCK INDUSTRIES } \\
\hline \multirow{5}{*}{$\begin{array}{c}\text { Block } \\
\text { sample }\end{array}$} & $\left(M_{1}-M_{2}\right)$ & $\overline{\left(M_{1}-M_{2}\right)}$ & $\overline{\left(M_{1}-M_{2}\right)}$ & $\overline{\left(M_{1}-M_{2}\right)}$ & $\left(M_{1}-M_{2}\right)$ \\
\hline & $M_{1}$ & $M_{1}$ & $M_{1}$ & $M_{1}$ & $M_{1}$ \\
\hline & $\times 100$ & $\times 100$ & $\times 100$ & $\times 100$ & $\times 100$ \\
\hline & Industry & Industry & Industry & Industry & Industry \\
\hline & $\mathrm{A}(\%)$ & $\mathrm{B}(\%)$ & $\mathrm{C}(\%)$ & $\mathrm{D}(\%)$ & $\mathrm{E}(\%)$ \\
\hline 1 & 11.8 & 9.5 & 13.7 & 11.9 & 7.7 \\
\hline 2 & 9.2 & 9.1 & 9.8 & 14.2 & 11.8 \\
\hline 3 & 6.4 & 10.0 & 11.2 & 13.4 & 8.5 \\
\hline 4 & 17.1 & 9.5 & 13.6 & 13.5 & 10.1 \\
\hline 5 & 15.5 & 6.0 & 14.5 & 11.9 & 9.6 \\
\hline 6 & 5.6 & 7.8 & 9.7 & 12.6 & 13.6 \\
\hline 7 & 5.0 & 10.6 & 10.1 & 8.5 & 11.2 \\
\hline 8 & 18.4 & 9.5 & 5.2 & 14.2 & 9.8 \\
\hline 9 & 12.4 & 8.6 & 7.2 & 10.4 & 12.1 \\
\hline 10 & 11.3 & 11.2 & 14.2 & 14.4 & 14.4 \\
\hline $\begin{array}{c}\text { Averag } \\
\text { e }\end{array}$ & 11.27 & 9.18 & 10.92 & 12.50 & 10.88 \\
\hline
\end{tabular}

TABLE XIII: WET COMPRESSIVE STRENGTH TEST RESUlt FOR THE FIVE BLOCK INDUSTRIES

\begin{tabular}{|c|c|c|c|c|c|}
\hline $\begin{array}{c}\text { Block } \\
\text { sampl } \\
\text { e }\end{array}$ & $\begin{array}{c}\left(M_{1}-M_{2}\right) \\
M_{1} \\
\times 100 \\
\text { Industry } \\
\mathrm{A}(\%)\end{array}$ & $\begin{array}{c}\left(M_{1}-M_{2}\right) \\
M_{1} \\
\times 100 \\
\text { Industry } \\
\mathrm{B}(\%)\end{array}$ & $\begin{array}{l}\frac{\left(M_{1}-M_{2}\right)}{M_{1}} \\
\times 100 \\
\text { Industry } \\
\mathrm{C}(\%)\end{array}$ & $\begin{array}{c}\left(M_{1}-M_{2}\right) \\
M_{1} \\
\times 100 \\
\text { Industry } \\
\mathrm{D}(\%)\end{array}$ & $\begin{array}{l}\frac{\left(M_{1}-M_{2}\right)}{M_{1}} \\
\times 100 \\
\text { Industry } \\
\mathrm{E}(\%)\end{array}$ \\
\hline 1 & 56,250 & 0.86 & 0.96 & 0.64 & 0.83 \\
\hline 2 & 56,250 & 0.94 & 1.03 & 0.62 & 0.70 \\
\hline 3 & 56,250 & 1.24 & 0.87 & 0.73 & 0.77 \\
\hline 4 & 56,250 & 0.86 & 0.81 & 0.80 & 0.76 \\
\hline 5 & 56,250 & 0.75 & 0.84 & 0.93 & 0.59 \\
\hline 6 & 56,250 & 0.72 & 0.70 & 0.69 & 0.89 \\
\hline 7 & 56,250 & 0,83 & 0.79 & 0.69 & 0.59 \\
\hline 8 & 56,250 & 0.87 & 0.86 & 0.53 & 0.55 \\
\hline 9 & 56,250 & 0.78 & 0.76 & 0.59 & 0.69 \\
\hline 10 & 56,250 & 0.73 & 1.06 & 0.78 & 0.82 \\
\hline $\begin{array}{c}\text { Aver } \\
\text { age }\end{array}$ & 0.86 & 0.87 & 0.70 & 0.72 & 0.77 \\
\hline
\end{tabular}




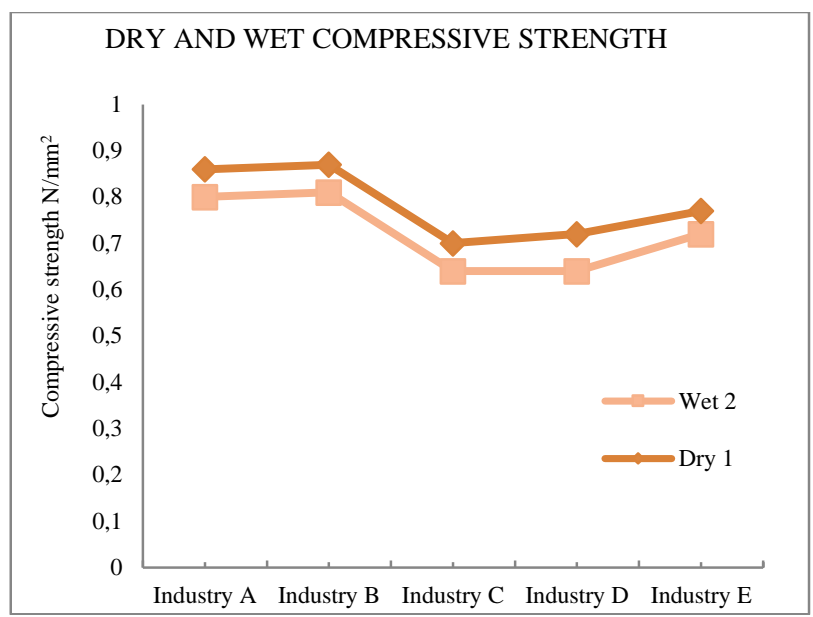

Fig. 9: Wet and Dry Compressive Strength of Blocks

\section{CONCLUSION}

In order to enhance the quality of sandcrete hollow blocks produced in Kogi State, the NIS was established by the Federal Government of Nigeria. The NIS: 87, 2007 standard specified the use of mix ratio 1:8 cement-sand proportion to achieve the minimum compressive strength value of $2.5 \mathrm{~N} / \mathrm{mm}^{2}$ for non-load bearing or $3.5 \mathrm{~N} / \mathrm{mm}^{2}$ for loadbearing walls as well as 0.45 water- cement ratio and maximum specified standards are being undermined by the producers of the sandcrete blocks and although there are adequate sanctions specified for violators, the agency lacks the willpower to enforce it. This action or inaction of government has given the producers the leeway to produce substandard blocks for commercial use.

The investigation revealed the strength properties of block samples of Nine inches (9") (450mm X 225mm X 225mm) sandcrete hollow block produced in some selected local government in Kogi State, Nigeria. None of the block samples from the five selected factories/block making industries meets the minimum strength requirement recommended by the Nigerian Industrial Standard (N1S:87, 2007) and National Building Code (NBC 2006) of $1.75 \mathrm{~N} / \mathrm{mm}^{2}$ as well as maximum specified $12 \%$ water absorption. Test results showed that block industry B has the highest average compressive strength value of $0.87 \mathrm{~N} / \mathrm{mm}^{2}$ while the block industry $\mathrm{C}$ has the least strength of $0.70 \mathrm{~N} / \mathrm{mm}^{2}$. From the test result the average water absorption capacity for block industry D is $12.5 \%$ which is more than the recommended standard by NIS:87(2007) hence, the sandcrete blocks at this industry are vulnerable to failure. Furthermore, based on the results of the mean compressive strength the blocks from the five blocks Industries are not fit to be used as building blocks. Adequate measures should be put in place by the governing bodies to check the menace of inadequate quality of blocks produced by the block making industries in Nigeria.

\section{ACKNOWLEDGEMENTS}

The authors would like to express their gratitude to Adama Samson, Emmanuel David and also the Department of Civil and Environmental Engineering, for their assistance during the course of the work.

\section{REFERENCES}

[1] [1] A. F., Ejeh S. P. (2000), Quality Studies of Sandcrete Hollow Blocks in Kawra State, an Independent research paper, Ahmadu Bello University Zaria, Nigeria, pp. 3 - 10

[2] British Standard Institutions. (1978). BS 882: Specifications for aggregates from natural sources. London, England

[3] Building Code, 2006, Federal Republic of Nigeria: National Building Code First Edition. Nigeria: National Building Cod

[4] Ejeh, S. P. and Abubakar, I. (2008). Sandcrete Hollow Blocks in Zamfara State. International Journal of Science and Technological Research, Vol. 5 No. 1, pp. 135-143.

[5] Ewa, D. E. and Ukpata, J. O. (2013), Investigation of the compressive strength of commercial sandcrete Blocks in Calabar, Nigeria. International Journal of Engineering Technology, vol. 3, No. 4, pp. $477-482$.

[6] Odeyemi, B. G., Ede, A. N., Egwuatu, C. and Jolayemi, J. (2015), Assessment of compressive strength of concrete produced from different brands of Portland cement. Civil and Environmental Research, vol. 7, No. 8, pp. $31-38$.

[7] Olanitori, LM. (2005). Assessment of Strength of Sandcrete Blocks Produced in Akure, Ondo State, Nigeria, Nigerian Journal of Industrial System Studies, Vol. 4, No. 1, pp. 63-72.

[8] Onwuka, D. O., Osadebe, N. N. and Okere, C. E. (2013). Structural Characteristics of sandcrete Blocks produced in South- East Nigeria. Journal of Innovative Research in Engineering and Sciences, 4(3), pp. 483- 490.

[9] Nigerian Industrial Standard, NIS 87:2007: Standard for sandcrete blocks. Lagos, Nigeria: Standard organization of Nigeria. Lagos, Nigeria: Standard organization of Nigeria.

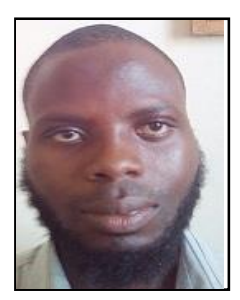

Quadri A. I. was born in Ogun State, Nigeria. He graduated with First Class and Distinction at both the Bachelor and Master Degree in Civil and Environmental Engineering Department, The Federal University of Technology, Akure Nigeria. He is Presently Working as an Assistant Lecturer in the same University. His area of specialization is Structural Engineering, He is a registered member of The Nigerian Society of Engineers (NSE) Email: aiquadri@futa.edu,ng

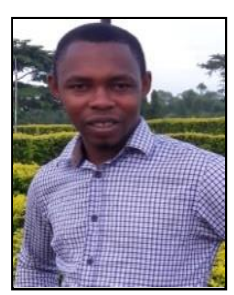

Ijesoh Lawrence was born in Nigeria. He graduated with a Higher National Diploma with honors Tech. in Civil Engineering from Federal Polytechnic, Auchi, Edo State, Nigeria in 2009 and went for NYSC between 2010 and 2011. He is currently working towards a PGD in Civil Engineering at The Federal University of Technology, Akure (FUTA). He has worked in the past as a CIVIL ENGINEER in different building and construction industries and He is currently working as a CIVIL ENGINEER in The Federal Ministry of Power, Works and Housing. Email: integrity4law@yahoo.com 